\title{
EXPLANATION OF PLATE XIII.
}

Fig. 1. Dentition of Conus: a, one fang, with its muscle remaining intact; $b$, extremity of the other fang, more highly magnified, to show the barbed processes more distinctly.

Fig. 2. Dentition of Terebra.

\begin{tabular}{|c|c|c|}
\hline & & \\
\hline $\begin{array}{l}\text { Fig. } 3 . \\
\text { Fig. } 4 .\end{array}$ & ” & $\begin{array}{l}\text { Bela. } \\
\text { Clavatula. }\end{array}$ \\
\hline Fig. 5. & ”, & Cyrtulus. \\
\hline Fig. 6. & $"$ & Fasciolaria. \\
\hline Fig. 7. & $"$ & Mitra. \\
\hline $\begin{array}{l}\text { Fig. } 8 . \\
\text { Fig. } 9 .\end{array}$ & " & Cynodonta. \\
\hline Fig. 10. & $”$ & $\begin{array}{l}\text { Buсстиит. } \\
\text { Pleurotoma. }\end{array}$ \\
\hline Fig. 11. & $"$ & Columbella. \\
\hline Fig. 12 . & , & Olivella. \\
\hline Fig. 13. & ” & Oliva. \\
\hline $\begin{array}{l}\text { Fig. } 14 . \\
\text { Fig. } 15 .\end{array}$ & $"$ & Harpa. \\
\hline Fig. 16. & $"$ & $\begin{array}{l}\text { Melo. } \\
\text { Marginella (from memorv). }\end{array}$ \\
\hline Fig. 17 . & " & Costellaria. \\
\hline Fig. 1 & , & Concholepas. \\
\hline
\end{tabular}

XIX.-Notes on the Fleshy Alcyonoid Corals (Alcyonium, Linn., or Zoophytaria carnosa). By Dr. J. E. GraY, F.R.S., V.P.Z.S., \&c.

This group of Corals was named Alcyonium by Linnæus and Pallas, but has been more lately subdivided into several genera. The polypes are social, generally with elongated tubular bodies, which are united to one another into a more or less fleshy crust or lobulated or branched coral. The inner substance between the tubular bodies is sometimes rather fleshy and permeated with vessels. The polypes and the flesh are often strengthened with various-shaped calcareous, sunken or superficial spicules; but there is no central axis as in the horny or stony Alcyonoid Corals.

In one genus at least (Paralcyonium) the lateral younger polypes are short, and there is direct communication between their bodies and the central cavity of the older or mother polype ; and in some other genera, as Sympodium and Erythropodium, which form only a thin crust, the body of the polype is short, as in the animals that form a thin bark on the central axis, e.g. in Gorgonia and Corallium.

The part of the polype at the base of the tentacles, and the tentacles themselves, are often armed with a series of spicules generally placed obliquely in two parallel series; they protect the polype when it is protruded: in some these spicules are so numerous as to prevent the complete contraction of the polype. 
The skin of the body and the fleshy substance between the bodies of this group of polypes are also studded with variousshaped calcareous spicules, the fusiform being the most common. The spicules were observed and studied by J. Ellis, and by various physiologists since his time, especially by Prof. Kölliker, in his 'Icones Histiologicæ;' but they require to be studied with more care and in a more philosophic manner, so as to divide the forms into different groups by observing the modifications which the spicules of each species undergo when being developed, and also in a larger number of kinds, before they can be used for the distinction of the genera and species.

Lamarck, in his Monograph on Alcyonium, first published in the 'Annales du Muséum,' and then in the 'Hist. Nat. des Anim. s. Vertèb.' (ii. 412), described many species that I have not been able to identify or place in this synopsis. Though most of them are described from specimens then in the Museum of the Jardin des Plantes, they are not further described or in any way referred to in Milne-Edwards and Haime's 'Coralliaires,' founded on specimens in that collection; so it is to be feared that the types have been lost. Some of them, like some of the Alcyonia figured by Esper and other zoologists, were, very likely, sponges. Considering the number of species that Ehrenberg and Quoy and Gaimard collected, and the very few localities from which the specimens described have been received, there must be very many species of these animals to be discovered, if they were only sought for in other localities. They are very easily preserved; so there is very little excuse for their not having been more collected and studied.

\section{Section I. DERMOCORALLIA.}

The coral crust-like, attached by the lower surface, or lobed and branched, with polypes on the whole of the exposed surface.

A. The coral crust-like, attached by the lower surface. The body of the polype short.

\section{Fam. 1. Antheliadæ.}

Coral crust- or skin-like, spreading, and attached by the lower surface. Polypes produced above the surface of the coral, not retractile. Spicules fusiform or cylindrical, spinous or tubercular.

This family is somewhat like Xeniadæ, and chiefly differs in producing buds only at the base of the cells; in this way the coral is expanded outward, and forms an incrusting plate. 


\section{Anthelia.}

Savigny, MS.; Lamarck, A.s. V. ii. 407 ; Lamx.; Blainv.;

Dana, Zooph. 602 ; M.-Edw. \& Haime, Corall. i. 109; Kölliker, Ic. Hist. 132.

Polypes not retractile, not branched by budding; the tentacles only retractile. Polype-body subcylindrical, prominent, from an expanded basal plate.

1. Anthelia glauca, Sav. Egypte, t. 1. f. 7 .

Hab. Red Sea.

2. Anthelia strumosa, Ehr.

Hab. Red Sea.

3. Anthelia pupurascens, Ehr., Sav. Egypte, t. 1. f. 5. Hab. Red Sea.

4. Anthelia Filippi, Kölliker, Ic. Hist. 132, t. 18. f. 41, 42. Hab. Guadaloupe.

5. Anthelia lineata, Verrill, t. 6. f. 9. Hab. Hongkong.

6. Anthelia Dujardinii, Dana. (Xenia Dujardinii, Templeton, Trans. Zool. Soc. ii. 25, f. 3-7.) $H a b$. Isle of France.

\section{Fam. 2. Sympodiadæ.}

Polype and tentacles completely retractile into the skin-like or crustaceous coral.

\section{Massarelia.}

Coral irregular-shaped, attached to the horny axis of a Gorgonia; outer surface hard, crustaceous, smooth; internal cork-like. Polypes completely retractile.

1. Massarella coralloides; B. M. (Gorgonia coralloides, Pallas, Zooph. 192 ; Esper, t. 32. Sympodium coralloides, Ehr. C. r. M. 61.)

Hab. - ?

2. Massarella rosea. (Sympodium roseum, Ehrenb.) $H a b$. West Indies.

3. Massarella vera. (Sympodium verum, Duchass. \& Michel. Suppl. 104.)

Hab. West Indies.

See Anthozoanthus parasiticus, Desh., Schleiden, Das Meer, t. 4, said to be a Lobularia on a Gorgonia. 


\section{Eunoella.}

Coral crust-like, thin. Polypes large, convex when contracted.

Eunoella gorgonoides. (Alcyonium gorgonoides, Ellis \& Soland. Zooph. 101, t. 9. f. 12. Sympodium gorgonoides, M.-Edw. Sertularia gorgonia, Pallas.) Hab. West Indies.

\section{Srmpodium.}

Ehrenb. Corall. 61; M.-Edw. \& Haime, Corall. i. 110 ; Kölliker, Ic. Hist. 141, t. 19. f. 7-9.

Coral expanded, fleshy, skin-like. Polype-cells small, papillose, not spined; polype and tentacles retractile, leaving a small superficial wart. Spicules fusiform or short, subcylindrical, tubercular or spinous.

1. Sympodium fuliginosum, Ehrenb., Savigny, Polyp.t. 1. f. 6. Hab. Red Sea.

2. Sympodium cceruleum, Ehrenb. Hab. Red Sea.

3. Sympodium poriferum, Verrill, Proc. Boston S. N. H. 1866. Hab. Panama.

4. Erythropodium.

Kölliker, Icon. Hist. 141 (1866), t. 12. f. 10, 11, t. 9. f. 6.

Coral incrusting, membranaceous; flesh of the coral studded with dark-red, large, subcruciate or subcylindrical tubercular spicules. Polype completely retractile into the cell, leaving only a slight convex edge. Tentacles nearly cylindrical, pectinate.

Erythropodium caribbcearum, Kölliker. (Xenia caribbcearum, Duchåss. \& Michel. Corall. Antilles, t. 1. f. 8-10.)

Hab. West Indies.

\section{OJEDA.}

Duchass. \& Michel. Corall. Antilles, 14, Supp. 104.

Coral like Sympodium. "Spicules, which resemble small nummulites, are so minute as to be only seen by the aid of the microscope; the edges are deeply cut out ; resembling a small many-rayed star, nummulitiform."

Ojeda luteola, Duchass. \& Michel. Corall. Antilles, 14. Hab. West Indies. 
Dr. J. E. Gray on the Fleshy Alcyonoid Corals.

B. The coral crust-like, convex, with more or less erect lobes. The polypes to the edge of the crust or the base of the stem, with long cylindrical tubular bodies; polypes retractile.

\section{Fam. 3. Lobulariadæ.}

Coral with a hard, crustaceous, smooth external coat. Polypes retractile.

* Polype-cell flat, not raised above the surface of the crust.

\section{Lobularia.}

$\uparrow$ Coral crust-like, with a few rounded lobes or cylindrical blunt branches.

1. Lobularia digitata, Lamk. (Alcyonium digitatum, Linn. A. lobatum, Pallas. A. exos, Spix. A. palmo, Esper, t. 9, dry. A. lacunosum, Esper, t. 14, dry. Lobularia grandiflora, Chamisso? Halcyonium palmo, Ehr., var. Alcyonium cydonium, Müller. Lobularia conoidea, Lamk. Cydonium Mülleri, Fleming.)

Hab. North Sea, Mediterranean.

B.M.

A. cydonium, Esper, t. 25. f. 1, 2, 3, looks like the section of a dry specimen of this coral.

2. Lobularia massa. (Alcyonium massa, Müller, Z. D. t. 81. f. 1,2. Massarium massa, Blainv. Sympodium massa, Ehrenb.)

$H a b$. North Sea.

3. Lobularia glomerata. (Alcyonium glomeratum, Johnston. A. rubrum and A. sanguineum, Hassall, Couch, Cornish Fauna, t. 13. f. 1.)

Hab. Coast of Cornwall (Couch).

4. Lobularia carnea. (Alcyonium carneum, Verrill, Bull. Mus. Comp. Zool. 35. A. digitatum, Stimpson.) Hab. North Sea.

5. Lobularia rubriformis, Ehrb. (Alcyonium rubriforme, Dana, Verrill, Mem. Boston S. N. H. i. 4.) Hab. North Sea.

6. Lobularia Verrillii. (Alcyonium —, n. s., Verrill, Rep. Essex Institute, 1865, p. 191.) Hab. Sea of Okhotsk (Verrill).

7. Lobularia mollis. (Alcyonium molle, Esper, t. 18 в, in spirits. A. granulatum, Esper, t. 24, dry.)

Hab. - , on a Fucus. 
8. Lobularia rigida. (Alcyonium rigidum, Dana.) Hab. Feejee Islands (Dana).

9. Lobularia Cë̈cis. (Alcyonium Cë̈cis, Duchass. \& Michel. Corall. Antilles, 14, Suppl. 104.)

Hab. West Indies.

10. Lobularia aquinoctialis, Duchass. Rad. Antilles, 21. Hab. West Indies.

11. Lobularia capitata. (Xenia capitata, Duchass. \& Michel. Corall. Antilles, 16, t. 1. f. 22, Suppl. 105.) Hab. West Indies.

12. Lobularia brachyclados, Ehrenb. (Alcyonium brachyclados, Dana.)

Hab. Red Sea.

13. Lobularia leptoclados, Ehrenb.

Hab. Red Sea.

t† Coral produced into acute finger-like lobes or branches; base compressed.

14. Lobularia Alava. (Alcyonium flavum, Quoy \& Gaim. Voy. Astrol. t. 23. f. 6, 7.)

Hab. Vanikoro.

15. Lobularia flabella, Quoy \& Gaim. Voy. Astrol. t. 23. f. $18-20$.

Hab. Australia.

tot Coral creeping; branches simple, erect, lamellar.

16. Lobularia muralis. (Alcyonium murale, Dana, Zooph. t. 58. f. 3.)

Hab. Tongatabu.

\section{Spharella.}

Coral hard, coriaceous, globular or subglobose, affixed by a slender peduncle, growing in clusters. Polypes scattered over the whole surface, quite retractile.

Spharella tuberculosa. (Alcyonium tuberculosum, Quoy \& Gaim. Voy. Astrol. t. 23. f. 4-8.)

Hab. Tongatabu.

\section{Chlorozon.}

Coral soft, divided into finger-like lobes, deep green. Polypes very small, irregularly disposed. Tentacles petal-like, ovate, lanceolate, connected by a membrane like a veil, and 
lacerated or ciliated at the tip. (See Quoy \& Gaim. Voy. Astrol. t. 23. f. 22, 23.)

Chlorozoa viridis. (Alcyonium viride, Quoy \& Gaim. Voy. Astrol. t. 23. f. 21-23.)

Hab. Vanikoro.

*** Polype-cell with a raised edge.

4. Rhodophyton, Gray, P. Z. S. 1865, p. 706.

Coral fleshy, with a hard crust, branched to the base. Polypecell with a raised edge. Polypes half-retractile.

Rhodophyton Couchii, Gray, P.Z. S. 1865, p. 706 (fig.). Hab. Cornwall (Couch).

B.M.

\section{Amicella.}

Coral thick at the base, branched, tree-like. Polype-cell rather prominent, covered with eight valves, each marked with two rows of spicules. Polypes quite retractile. "Tentacles simple, clavate" (Quoy).

Amicella amicorum. (Alcyonium amicorum, Quoy \& Gaim.

Voy. Astrol. t. 22. f. 13-15. Nephthea amicorum, Blainv. Ammothoa amicorum, M.-Edw.)

Hab. Tongatabu.

\section{Section II. PODOCORALLIA.}

The coral pedunculated, the lower portion stem-like, barren, the upper lobed or branched, with the polypes on the surface. The polypes with an elongated tubular body.

A. Coral with a coriaceous or crustaceous minutely granular outer surface, with more or less numerous internal spicules. Polypes retractile or semiretractile.

\section{Fam. 4. Alcyoniadæ.}

The coral fleshy, divided into lobes or branches above, bearing the polypes on all sides. Stem more or less coriaceous externally. Polypes retractile.

\section{Alcyonium.}

Coral erect; base thick, smooth, barren ; upper part divided into subcylindrical lobes. Polype-cells even. Polypes small, retractile.

Kölliker says $A$. palmatum has a rudimentary axis. (See Icon. Hist. t. 12. f. 4.) 
Dr. J. E. Gray on the Fleshy Alcyonoid Corals.

$$
\text { * Coral fleshy. }
$$

1. Alcyonium palmatum, Pallas. (A. exos, Gmelin, Esper, t. 2 ; Ellis, Phil. Trans. 1763, t. 20. f. 9. Lobularia palmata,

Lamk. L. digitata, Chiaje.) Hab. Mediterranean. B.M.

2. Alcyonium Sarsii. (A.palmatum, var., Sars, Kölliker, Icon. Hist. 132.)

Hab. North Sea.

3. Alcyonium aurantium, Quoy \& Gaim. Voy. Astrol. t. 22. f. 16-18. (Lobularia aurantiaca, Lamk.)

$H a b$. New Zealand. B.M.

$$
\text { ** Coral crustaceous. }
$$

4. Alcyonium stellatum, M.-Edw. Ann. Sc. Nat. iv. 1835 , t. 16 ; Corall. i. 116 , t. 1 a. f. 2. $H a b$. Coast of France.

\section{Danella.}

Coral soft; stem thick, barren, not dilated at the base; branches slender, cylindrical, ascending. Polypes small, on the branches; spicules very abundant in all parts of the stem.

* Coral coriaceous, branches blunt.

1. Danella conferta. (Alcyonium confertum, Dana, Zooph. t. 57 . f. 7.)

$H a b$. Feejee Islands.

** Coral soft, branches acute.

2. Danella flexibilis. (Alcyonium flexibile, Quoy \& Gaim.) Hab. Vanikoro.

3. Danella fegeensis. (Alcyonium flexibile, var., Dana, Zooph. t. 57 . f. 6.$)$

Hab. Feejee Islands (Dana).

\section{Amocella.}

Coral fleshy, smooth, arising from a more or less extended, compressed, horizontal base, with thick, erect, smooth, sterile stems divided above into lobes or branches, covered on all sides with retractile polypes.

1. Amocella pauciflora, Savigny, Egypte, t. 1. f. 8. (Lobularia pauciflora, Ehrenb. Ammothoa virescens, part., Audouin. Alcyonium pauciflora, Dana.)

Hab. Red Sea. 
Dr. J. E. Gray on the Fleshy Alcyonoid Corals.

2. Amocella polydactyla. (Lobularia polydactyla, Ehrenb.) $H a b$. Red Sea.

3. Amocella? trichanthema. (Alcyonium trichanthemum, Dana, Zooph. t. 56. f. 1.)

Hab. Feejee Islands.

\section{Fam. 5. Sarcophytidæ.}

The coral discoidal or hemispherical, pedicelled; stem and under surface barren, rather coriaceous, granular. Polypes on the upper surface of the frond, retractile.

\section{Sarcophyton, Lesson.}

Coral agaric-shaped, soft, fleshy, externally soft; stem cylindrical, formed of cylindrical tubes.

1. Sarcophyton glaucum, Verrill. (Alcyonium glaucum, Quoy \& Gaim. Voy. Astrol. t. 22. f. 11, 12.)

Hab. Tonga (Quoy); Feejee (Verrill).

B.M.

2. Sarcophyton lobatum, Lesson, Voy. Bélanger, t. 2. Tentacles simple?

$\mathrm{Hab}$.

3. Sarcophyton agaricum, Stimpson, Verrill. Hab. Japan.

2. Areocella.

Coral rather rigid, stipitate, very broadly expanded, sinuate on the edge; upper surface areolated, areolæ hexagonal, each surrounded by a series of small tubercles. Polype in centre of each areola.

Areocella lata. (Alcyonium latum, Dana, Zooph. t. 56. f. ?, t. 58. f. 7. Sarcophyton latum, Verrill.)

Hab. Tongatabu, Feejee Islands.

\section{Cladiella.}

Coral half-ovate or obconical, in clusters, below tapering to a small base, barren, above flat. Polypes retractile.

1. Cladiella spharophora. (Lobularia sphcerophora, Ehrenb. Alcyonium spharophora, Dana.)

Hab. Red Sea.

2. Cladiella brachycladia. (Alcyonium brachycladium, Dana, t. 57. f. 8.)

Hab. Tongatabu. 


\section{Fam. 6. Bellonelladæ.}

Coral capitate; stem thick, with a coriaceous granular outer surface, grooved, showing the tubular form of the bodies of the polypes above; head hemispherical. Polype-cells cylindrical, with a plaited mouth. Polypes retractile.

Chiefly differs from Xeniada in the stem being more coriaceous and the polypes retractile into the tubular projecting cells.

\section{BeLlonella.}

$$
\text { Gray, P. Z. S. } 1862 \text {, p. 35, figs. 3, } 4 \text {. }
$$

Coral cylindrical, simple, with a convex head, with subcylindrical, truncated, divergent polype-cells on the upper, nearly flat surface, with eight grooves on the edge when the tentacles are enclosed. Tentacles pinnate.

1. Bellonella granulata, Gray, P. Z. S. 1862, p. 35, fig. Hab. Bellona Reefs.

B.M.

2. Bellonella? capitata. (Lobularia capitata, Duchass. \& Michel. Corall. Antilles, 21.)

Hab. West Indies.

\section{Fam. 7. Xeniadæ.}

Gray, Ann. \& Mag. Nat. Hist. 1859, iv. 443.

Coral soft and fleshy; stem simple or slightly branched, smooth or minutely granular. Polypes clustered on the rounded ends of the branches, not retractile; skin of the stem and polypes to the end of the pinnules strengthened with spicules.

1. Xenia, Savigny = Crepitularia, Valenc.

Coral creeping, fleshy; stem erect. Internal spicules few.

1. Xenia umbellata, Savigny, Egypte, Polypes, t. 1. f. 3. Hab. Red Sea (Savigny).

2. Xenia fuscescens, Ehrenb. Hab. Red Sea.

3. Xenia ccerulea, Ehrenb. Hab. Red Sea.

4. Xenia samoensis, Kölliker, I. H. 133, t. 12. f. 1, 2. Hab. Samoa Island.

2. LORIDELLA.

Coral erect; stem thick, with a contracted base; surface co- 
riaceous, with imbedded fusiform spined spicules. "Tentacles with lobes on all sides" (Quoy).

1. Loridella subviridis. (Cornularia subviridis, Quoy \& Gaim. Voy. Astrol. iv. 256, t. 22. f. 5-7.)

Var., Quoy \& Gaim. l.c. t. 22. f. 8-10.

Hab. Feejee.

2. Loridella florida. (Actinantha forida, Lesson, Voy.Coq.85, t. 1. f. 3 = Xenia florida, Dana.)

3. Loridella elongata. (Xenia elongata, Dana, Zooph. 606, t. 57. f. 5.) $\mathrm{Hab}$.

4. Loridella rosea. (Xenia ccerulea, var., Dana, Zooph. 605, t. 57. f. 3.)

Hab. Feejee.

\section{Wardella.}

Coral simple; stem simple, with very numerous smooth internal spicules forming a thick spongy web. Polypes not retractile.

Wardella indivisa. (Xenia indivisa, Sars, Kölliker, I. H. 133.)

Hab. Naples (Sars).

B. Coral cellular; the surface of the coral and outer side of the polypecells covered with opaque, rugose, fusiform spicules. Polype retractile.

a. Stem, branches, and polype-cells covered with spicules.

\section{Fam. 8. Nidalidæ.}

Coral simple or branched; stem cylindrical, cartilaginous, with a crustaceous skin and imbedded spicules. Polypes on the upper surface of a hemispherical head, with prominent large conical polype-cells; stem and polype-cells covered with large fusiform spicules.

\section{Nidalia.}

\section{Gray, P. Z. S. 1835 , ii. 59.}

Coral cylindrical, branched, with an expanded hemispherical head with large conical cells on the upper surface; cells covered with spines.

Nidalia occidentalis, Gray, P. Z. S. iii. 30 ; P. Z. S. 1857, p. 129, t. 7. (not t. 3. f. 2).

Hab. - ? 
128 Dr. J. E. Gray on the Fleshy Alcyonoid Corals.

\section{Fam. 9. Spoggodidæ.}

Coral membranaceous, cellular, branched, the outer surface covered with opake fusiform spicules. Polype-cells at the ends of the branchlets, and surrounded by a series of projecting spicules. Polypes retractile.

\section{Spoggodes, Lesson. \\ Gray, Proc. Zool. Soc. 1862.}

Polypes crowded together at the ends of the branchlets, the groups more or less surrounded by larger spicules.

1. Spoggodes florida, Gray, P. Z. S. 1862, t. 4. f. 1, 2, 3. (Alcyonium floridum, Esper, t. 16 . Xinia florida, Lamk. Neptea florida, Blainv. Spoggodes celosia, Lesson.) Hab. Philippines (Cuming).

B.M.

2. Spoggodes spinosa, Gray, l. c. t. 4. f. 5-7.

Hab. New Guinea.

B.M.

3. Spoggodes capitata, Verrill.

Hab. Hongkong.

B.M.

4. Spoggodes arborescens, Verrill.

$H a b$. Feejee Islands.

2. Spoggodia.

$$
\text { Gray, P. Z. S. 1862, p. } 29 .
$$

Polype-cells subcylindrical, prominent from the sides, or forming the tips of the branchlets.

1. Spoggodia unicolor, Gray, l.c. f. 1, 2.

Hab. Bellona Reefs.

B.M.

2. Spoggodia divaricata, Gray, 1.c. f. 3, 4 . Hab. New Guinea.

3. Spoggodia ramulosa, Gray, 1. c. f. 5, 6 .

Hab. Bellona Reefs.

B.M.

4. Spoggodia gracilis. (Spoggodes gracilis, Verrill.) Hab. Loochoo Islands.

b. Stem with a coriaceous granular skin; branches and polype-cells strengthened with superficial fusiform spicules.

Fam. 10. Nephthyadæ.

Gray, Ann. \& Mag. Nat. Hist. 1859, iv. 444.

Coral fleshyy, cellular, branched; stem coriaceous or granular 
externally; branches and polype-cells with superficial spicules. Polype-cells subcylindrical, incurved. Polypes retractile.

\section{Nephthya, Savigny.}

Coral fleshy, with a large horizontal basal mass. Stem erect, divided above into heads or spikes of polypes; branches and polype-cells with many large superficial and few internal spicules. Polype-cells crowded on all sides of the ovate clubshaped terminal branchlets. Polypes half-retractile, leaving an incurved tubercle covered with fusiform spicules.

1. Nephthya Savignii, Ehrenb., Savigny, Polyp. Egypte, t. 2. f. 5. (N. Chabrolii, Audouin. N. innominata, Blainv.) Hab. Red Sea.

B.M.

2. Nephthya polyanthus. (Ammothea polyanthus, Duchass. \& Michel. 15, t. 1. f. 6.)

Hab. West Indies.

3. Nephthya parasitica. (Ammothea parasitica, Duchass. \& Michel. 15, t. 1. f. $3,4,5$.)

Hab. West Indies.

4. Nephthya aurantiaca, Verrill.

Hab. China Seas.

\section{Ammothea, Savigny, Pol. Egypte.}

Coral fleshy, with a horizontal creeping basal mass. Stem erect, divided above into heads or spikes of polypes. Stem and branches with very few minute superficial spicules, and with many internal spicules. Polype-cells crowded on all sides of the oval club-shaped terminal branchlets; polype-cell subcylindrical, incurved, lobed at the mouth.

Ammothea virescens, Savigny, Polyp. Egypte, t. 2. f. 6. (Nephthea Cordieri, Audouin. Neptea Savignii, Blainv.) Hab. Red Sea.

B.M.

\section{Capnella.}

Coral erect; stems clustered, coriaceous, granular, divided into short branches; outer surface studded with small, flat, smooth, irregular-shaped spicules. Polype-cells crowded and imbricate on all sides of the oval club-shaped branchlets; polype-cell campanulate, slightly eight-lobed. Polypes retractile.

Capnella imbricata, Quoy \& Gaim. Voy. Astrol. iv. 281, t. 23. f. 8-14. (Ammothea imbricata, M.-Edw.)

$H a b$. New Zealand, Australia.

B.M. Ann. \& Mag. N. Hist. Ser. 4. Vol. iii. 
4. Morchellana, Gray, Proc. Zool. Soc. 1862, p. 30.

Coral clavate; stem thick, contracted below; outer surface coriaceous, granular; skin of branches thin, studded with large, opaque, fusiform spicules. Upper part divided into short, conical, spreading branches, closely covered with subcylindrical incurved polype-cells.

Morchellana spinulosa, Gray, P. Z. S. 1862, p. 31, fig. at page 30 .

$H a b$. Indian Ocean.

B.M.

See Alcyonium spongiosum, Esper, Zooph. t. 3. Ammothea phalloides, Lamk. Figured from a dry specimen.

c. Coral soft, membranaceous, cellular, smooth, with the polypes at the ends of the fleshy branches. Polypes partly retractile, leaving a subspherical terminal head to the branchlets; a few imbedded spicules near the mouth and in the tentacles. Lower part of the coral simple or retractile into a tubular spinulose sheath.

\section{Fam. 11. Lemnaliadæ.}

Coral simple at the base; stem formed of the clustered cylindrical tubular bodies of the polypes; outer surface smooth, without spicules.

Known from Nephthyada by the polype-cell being pedicelled, and the stem and branches of the coral not being covered with superficial fusiform spicules.

\section{Lemnalia.}

Gray, Ann. \& Mag. Nat. Hist. 1868, ii. p. 442.

Coral-stem forming an expanded creeping base. Polypecells racemose.

1. Lemnalia Jukesii, Gray, l.c. fig. 1. Hab. —?

2. Lemnalia terminalis. (Alcyonium terminale, Quoy \& Gaim. Voy. Astrol. t. 23. f. 15-17.)

Stem unknown. Spicules fusiform, smooth, small, flat, irregular-shaped (Quoy).

Hab.

3. Lemnalia nitida. (Ammothea nitida, Verrill, Bull. Mus. Comp. Zool. 39.)

Hab. Zanzibar (Verrill). Stems clustered.

2. Verrilliana. =

Coral soft, branched. Stem tapering, cylindrical, longi- 
tudinally grooved. Polypes clustered together on all sides of the ends of the branches, forming an ovate-lanceolate group or thyrse. Polype-cell cylindrical, with a subglobular head when the polype is contracted.

1. Verrilliana ramosa. (Alcyonium ramosum, Quoy \& Gaim. Voy. Astrol. iv. 275, t. 23. f. 8-11. Ammothea ramosa, M.-Edw.)

Hab. New Granada (Quoy).

2. Verrilliana thyrsoides. (Ammothea thyrsoides, Ehrenb. nec Nephthya thyrsoidea, Verrill.)

Hab. Red Sea (Ehr.); Cape of Good Hope (Verrill).

\section{Fam. 12. Paralcyoniadæ.}

Coral membranaceous, branched above, smooth, with minute dermal spicules near the mouths of the polypes; the bodies of the polypes opening into each other, making a common cavity. The coral retractile into a tubular sheath covered with large dermal spicules. Tentacles retractile.

Paralcyonium, M.-Edw. (Alcyonidia, M.-Edw. 1835.) Paralcyonium elegans, M.-Edw. Corall. i. 130, t. 1 a. f. 1 . (Alcyonidia elegans, M.-Edw. Ann. Sc. Nat. 1835, iv. t. $12,13$.

$H a b$. Algiers.

XX.-Notice of a Gigantic Species of Batrachus from the Seychelle Islands. By A. Günther, F.R.S.

The British Museum has lately received, through Lieut.-Col. Playfair, the dried head of a gigantic Acanthopterygian Fish, which was captured by Swinburne Ward, Esq., H.M. Civil Commissioner for the Seychelles. To judge from the head, this fish appears to be equal in bulk to any of the species of Histiophorus, if, indeed, it does not exceed them in size. I was previously acquainted with this fish from a pair of jaws only, preserved in the British Museum for a long time; but I was unable to form any opinion from these fragments as regards the systematic position of the fish to which they belonged. 'Although one character of Batrachus, viz. prominent spines of the opercles, is absent, or at least not conspicuous in the head before me, its appearance and structure is that of the species of this genus; and as I do not know of a species to which it may be referred, I regard this fish as undescribed, 


\section{$2 \mathrm{BHL}$ Biodiversity Heritage Library}

Gray, John Edward. 1869. "XIX.-Notes on the fleshy Alcyonoid Corals (Alcyonium, Linn., or Zoophytaria carnosa)." The Annals and magazine of natural history; zoology, botany, and geology 3, 117-131.

https://doi.org/10.1080/00222936908695893.

View This Item Online: $\underline{\text { https://www.biodiversitylibrary.org/item/79672 }}$

DOI: https://doi.org/10.1080/00222936908695893

Permalink: https://www.biodiversitylibrary.org/partpdf/62483

\section{Holding Institution}

Smithsonian Libraries

\section{Sponsored by}

Smithsonian

\section{Copyright \& Reuse}

Copyright Status: Public domain. The BHL considers that this work is no longer under copyright protection.

This document was created from content at the Biodiversity Heritage Library, the world's largest open access digital library for biodiversity literature and archives. Visit BHL at https://www.biodiversitylibrary.org. 